\title{
ANALYSIS OF LOVE BY USING TRINGULAR THEORY OF LOVE BY STERNBERG IN BREAKING DAWN NOVEL BY STEPHENIE MEYER. (A PSYCHOLOGICAL STUDY)
}

\author{
Fazriyani S Mahmud \\ English Literature Department, Faculty of Cultural Science, \\ Universitas Muhammadiyah Gorontalo \\ fazriyanimahmud01@gmail.com
}

\begin{abstract}
Love is something that everyone may have. Even love is the right of every human being in the world, so that everyone has the right to love and be loved by others. Generally love is a form of emotion that contains attraction, sexual desire, and attention to someone. This shows that love has several components in it including intimacy, passion, and commitment. This research is focused on analyzing love experiences by using the triangular theory of love by Sternberg on some of the characters in the novel Breaking Dawn by Stephenie Meyer. This research used descriptive qualitative method and used Sternberg's theory to analyze the experience of love in the breaking dawn novel. The result of this research has three components in love including intimacy, passion, and commitment.
\end{abstract}

Keywords: Love, Triangular of Love, Intimacy, Passion, Commitment

\section{INTRODUCTION}

Literature is a form and result of the work of creative arts whose objects are human and life by using language as a medium. Language in literary works has an implicit meaning and has aesthetic value. So, the writer or author must be able to process the language carefully so that it can be enjoyed by the reader. Semi (1993: 8) argues that as a creative work, literature must be able to produce a beautiful creation and try to channel the needs of human beauty. Literature is also interpreted as an imaginative work of fiction because it can transform reality into the text. Literature presents the world in words, which are not the real world, but the world that might exist.

Literary works as imaginary works offer various human problems and realities in their environment. The author fully understands the various problems that are then expressed again through means of fiction in accordance with his views (Nurgiyantoro, 2007: 1). The world of fiction contains more possibilities, but it cannot escape the events both directly and indirectly experienced by the 
author. So, through that fictional world the author expects the reader to be able to know the ideas, messages, feelings, and mandates contained in a literary work.

Literary works cannot be separated from the role of an author. The creator of literature is a part of society that intentionally or not devotes the problems of personal life and society as objects with spiced imagination to become a meaningful work. Real life generally includes relationships between people, between communities and between events. Events that occur often become literary material because literary material can be said as a reflection of someone's life or society.

One form or genre of literary works is a novel. According to Nurgiyantoro (2007: 3), as a literary work, novels are imaginative works based on awareness and responsibility in terms of creativity as works of art. Each novel is more or less a matter of human life, but many people are interested in novel literature that tells a good love story between love for God, parents and lovers, as found in the novel breaking dawn whose author Stephenie Meyer wrote.

As the writer who was interested in the love story contained in breaking dawn's novel by Stephenie Meyer, As told in this novel, there are many elements of romance or romantic stories in particular there are several characters told which according to the writer are very interested in studying this novel. Especially in this day and age, many of them like works that have the theme of love stories, as according to experts suggest that love is a topic loved by every circle, both young and old, is evident from song lyrics, drama, theater, poetry, poetry, comics, novels and even gossip about love (Wisnuwardhani, 2012). Even now love is a popular topic in scientific research (Taylor, 2009).

The writer will analyze the love style using the tringular theory of love by Stenberg, which according to this theory states that love has three main forms: passion, intimacy, and commitment, which are explained as follows (Dariyo, 2003).

\section{RESEARCH METHOD}

This chapter discussed the design of research, source of data, technique of collecting data, technique analyzing data. 


\section{Design of Research}

This research is a qualitative research. The writer use qualitative method to an analysis love style use tringular theory of love by Stenburg in Breaking Dawn Novel by Stephenie Meyer. The qualitative research refers to the meaning definitions, concepts, characteristics and description of things.

\section{Source Of Data}

There are two sources of the data, the primary data and secondary data. The primary data are taken from the information in Breaking Dawn novel by Stephenie Meyer. The secondary data were taken from Several of jurnals about love style, journal and article of tringular of love theory by Stenburg.

\section{Technique of Collecting Data}

The writer read the novel for several times. It is to make the writer easily to know the character and the story the especially about the love story between characters in the novel. Technique to collecting data in this research is using literary study to know the theory, reading the book in library and search for information through the internet. Conducted the descriptive method to describe how a case, circumstances, attitudes, relationships, or source of problem that becomes the object of this research that brought closer to the values of the psychological and educational for the readers.

\section{Technique of Analyzing Data}

The writer completed the data collecting to analyze love style using tringular theory of love by Stenburg on Bella and Edward Cullen In Breaking Dawn Novel by Stephenie Meyer with technique of analyzing the data that adjusted with steps of course analyze methods. In this case ever stated by Widodo (2015) he argues that there is not correct way in absolute terms to organize, analyze and interpret qualitative data. Therefore, the procedure of data analysis in this study are based on number of theories and adapted to the purpose of research. From this point of view, the writer formulates several steps in analyzing the data in this research. They are: 
Identifying: the writer identified the love style by reading and taking some comprehension about the story.

Classifying : the writer classified the love style based on the data which had been taken on the movie. Then the writer identifies the data based on tringular of love theory by Stenburg.

Interpreting : the writer interpreted the script to get the deep uderstanding about the data discussion.

Concluding : in this step, the writer draws the conclussion of the discussion as the result of this research.

\section{Psychological Approach}

Literary psychology is basically a study related to the existence of psychiatric elements in the characters in the world of fiction contained in literature. Walgito (in Fananie, 2000) argues that psychology is a branch of science whose object of study is humans, because the words psyche or psicho contain the notion of "soul". Thus, psychology implies "science of the soul". According to Plato (in Prawira 2006) psychology is the psychology of philosophy, the science that studies nature, the nature and life of the human soul.

Literary psychology studies certain psychological, psychological phenomena experienced by the main characters in literary works when responding or reacting to themselves and their environment. Thus, psychiatric symptoms can be revealed through the behavior of characters in a literary work.Literary psychology research is carried out in two ways. First, through understanding psychological theories then an analysis of a literary work is held. Second, by first determining a literary work as an object of research, then determined psychological theories that are considered relevant for conducting analysis (Ratna, 2004).

According Roekhan (in Endaswara, 2011) psychology literature will be supported by three approaches simultaneously. First, the textual approach, which examines the psychological aspects of the characters in literature. Second, the Receptive-pragmatic approach, which examines the psychological aspects of the 
reader as a connoisseur of literature that is formed from the influence of works he had read, and the process of the reception reader to enjoy literature. Third, expressive approach, which examines the psychological aspects of the author when projecting the creative process through his work, both as a writer of personal and community representatives.

From various explanations, it can be concluded that the psychology of literature studies phenomena, certain psychology experienced by the main characters in literary works when responding or reacting to themselves and their environment.

\section{RESEARCH FINDING AND DISCUSSION}

This chapter presents about finding and discussions. This research as a result of triangular of love by Sternberg analysis in Breaking Dawn novel by Stephenie Meyer. This research focus on how the triangular of love from the characters on this novel that used theory by Sternberg that appears in the novel itself. The result is divided into three concepts such as intimacy, passion and commitment.

\section{a. Intimacy}

Edward and I were together, and I'd married him. That was the big one. But I'd also accepted all his outrageous gifts and was registered, however futilely, to attend Dartmouth College in the fall. Now it was his turn. (pg. 19 engaged-Breaking dawn).

In this data it is told that Bella wants to be with Edward is the most important thing even though compared to other things. The intimacy in this data is shown by Bella's attitude which reveals that the more important thing is Edward and Bella getting married and living together. All gifts from Edward to Bella which is a form of appreciation for Bella. And Bella who still wanted to experience university entrance was granted by Edward. In this case the desire to be together and respect each other is one form of intimacy in the relationship as expressed by several experts including by Olforsky (in Marcia, et al., 1993) defines the ability of intimacy as the ability to form and maintain intimate or intimate relationships, which are usually seen in the form of closeness, respect for individuality, openness, communication, responsibility, reciprocity, commitment 
and sexuality. As also said by Dariyo (2008) the intimacy happens because each individual feels each other needs and complements one another, so that they feel unable to live alone without help and the presence of a partner on their side.

I'm hoping you won't wake and notice my absence, but, if you should, I'll be back very soon. I've just gone to the mainland to hunt. Go back to sleep and I'll be here when you wake again. I love you (Pg. 108 unexpectedBreaking Dawn).

Edward who told Bella through a letter that was left while Bella was still asleep. Edward hopes that Bella is still awake in her sleep until Edward can get back with Bella, but Bella has awakened from her sleep when Edward hasn't returned. But Edward had already thought about it if Bella woke up when she wasn't home yet. Good communication has done by Edward by leaving a letter so that Bella does not feel anxious about Edward who left Bella while sleeping.

Intimacy in this data is aimed at Edward's attitude which left a piece of a letter aiming that Bella does not worry about Edward who was about to leave while Bella was still asleep and did not forget the word of love shown towards Bella. As explained by Sternberg (2009). During the initial stages of the relationship, intimacy begins with a low level but will increase rapidly when the couple communicates and opens with one another. Edward is trying to have a good communication relationship with Bella. Prefer to leave a letter compared to having to wake Bella up directly, it is also a way for Edward to be more respectful of a partner when Bella is sleeping. Edward's intimacy with Bella was the same as what was expressed by Yudisia (2013) states that intimacy can be realized by reducing selfishness, arrogance, and not wanting to obey her partner.

The intimacy in this data is shown when Bella says that Jacob is the best man and Jacob uses the word "Honey" on Bella. Bella who openly expressed the feeling that Bella was happy with Jacob's arrival, according to Erikson (in Kroger, 2001) defines intimacy refers to feelings of mutual trust, openness and sharing in a relationship. In this case only that Jacob was a good friend of Bella. The friendly relationship Bella and Jacob showed illustrates what was said by Sternberg (2009) the component of intimacy can not only occur in romantic relationships but can occur in relationships of love for children, or love of friends. 
"Do you miss it?" I asked him when her song was done. It wasn't the first time we'd spoken, but we weren't exactly keeping up a conversation, either. "Miss what?"he murmured. "All of it. The warmth, the soft skin, the tasty smell...I'm not losing anything at all, and I just wondered if it was a little bit sad for you that you were." (Pg. 447 surprise-breaking dawn).

Bella, who was having a conversation with Edward, with so many warm questions.intimate conversation that looks quite romantic shown by Bella with Edward. They are both so responsive to their conversation.

The intimacy in this data shows that the warmth between the two of them in their small conversation, which implies that their relationship has become a necessity that they respect each other and love each other. As said by Sternberg in Santrock (2002) intimacy is an emotional feeling about warmth, closeness, and sharing in relationships.

\section{b. Passion}

"Charlie, I relized that I've gone about this out of order. Traditionally, I should have asked you first. I mean no disrespect, but since Bella has already said yes and I don't want to diminish her choice in the matter, instead of asking you for her hand, I'm asking you for blessing. We're getting married, Charlie. I love her more than anything in the world, more than my own life, and----by some miracle----she loves me that way, too. Will you give us your blessing?" (pg. 13 engaged-Breaking dawn).

Edward is about to ask for his blessing from his father Bella that he wants to marry his daughter. The passion in the data was seen when Edward and Bella ventured to face Charlie as Bella's father to ask for blessing that Edward wanted to marry Bella. Edward and Bella who want to continue their relationship at the marriage level because they do not want to be separated and realize their feelings in a marriage bond. As said by Yudisia (2013), that passion is the side of love that requires physical proof and as also according to Sternberg (in Sears, 2009) states that passion contains impulses that cause strong emotions in love relationships.

I wanted the complete experience before I traded in my warm, breakable, strong... and unknown. I wanted a real honeymoon with Edward. And, despite the danger he feared this would put me in, he'd agreed to try. (pg. 19 engaged-breaking dawn). 
In this data it is told that Bella realized that she would not become human again when she married Edward. But Bella who loves Edward so much does not care about it, but he wants a honeymoon with Edward.

Passion in this data when where Bella wants to feel the real honeymoon with Edward. Bella's desire to be alone with Edward, took the time to want to further complement the experience with Edward until Bella wanted to feel the honeymoon with Edward. On the other hand they are not the same creature, so there is concern when they do it. But a strong passion made them agree to have a honeymoon together. As according to Hatfield \& Walster (in Sternberg, 1986) states that passion is a condition that deeply makes a person always want to be with the person he loves.

At first I thought he would let me go alone, but then as I moved a few steps away, his blank eyes flickered to life. "I'll come with you," he said quietly. "We'll meet you at home, Carlisle." Carlisle nodded,and the others left. I waited until they were out of sight, and then I looked at Edward questioningly. "I couldn't let you walk away from me," he explained in a low voice. "it hurt just to imagine it." (Pg. 520 Defection-Breaking dawn)

In this data explains that Bella who wants to leave, on the other hand Edward who must accompany Bella and will not let Bella go alone without anyone protecting Bella. The passion in this data is shown Edward who will not let Bella go far without Edward. Edward who wants to be beside Bella shows that there is Edward's passion to always be with Bella or someone who wants to be beside his partner. Meanwhile according to Hatfield \& Walster (in Sternberg, 1986) states that passion is a condition that deeply makes a person always want to be with the person he loves.

Edward took my hand, I couldn't stop marveling at the smoothness, the comfortable temperature of his skin, and darted through the backyard to the edge of the river. I went along with him effortlessly. (pg. 378 first huntBreaking Dawn).

This data explains that Bella was incessantly admiring Edward. Edward's touch made him really admire Edward and felt comfortable with Edward. The passion in this data is shown by Bella's comfortable condition, Bella's expression who greatly admires Edward with Edward's touch of Bella that makes the comfort 
Bella feels with Edward. The comfort that Bella feels when she is with Edward in physical contact, in this data where Edward is holding Bella's hand, so Bella feels comfortable when touching Edward's skin. As stated by Yudisia (2013), that passion is the side of love that requires physical proof.

I was about to take advantage of the fact that he hadn't gotten around to setting me back on my feet and that his wits-scramblingly beautiful face was only inches away when he said, "We're lucky Esme thought to add an extra room. No one was planning for Ness-Renesmee." (Pg. 444 surprisebreaking dawn).

Bella who uses that she is still in Edward's arms. Bella who really loves Edward looks natural for Bella to always be with Edward wherever Bella is, all Bella wants is to want to be with Edward.

Passion in this data is seen in their romance, Bella who uses herself in Edward's arms. they both felt fortunate because the cottage they lived in had a room that was enough to vent their passion as their relationship needs. As according to Dariyo (2008) defines the component of arousal as a physiological element that causes a person to feel physically close, to enjoy or feel physical touch, or to have sexual relations with his life partner.

I didn't even glance at the doors. There was nothing else in the world but him again, his arms curled under me, his sweet breath on my face, his lips just inches from mine, and there was nothing that could distract me now, newborn vampire or not. (Pg. 445 surprise-breaking dawn).

This data explains that Bella who has been exhausted and enjoys being together with Edward, even Bella said that there is nothing else in the world except Edward.

Passion in this data is clearly seen in Edward's partner with Bella who is enjoying their togetherness; their romanticism that is seen by their sense of belonging is marked by physical closeness that occurs between Edward and Bella. Togetherness that exists between the two of them is more important for Bella than anything else in the world. As said by Hatfield \& Walster (in Sternberg, 1986) states that passion is a condition that deeply makes a person always want to be with the person he loves. 


\section{Commitment}

"You sure about this?" Charlie demanded, glaring at me. "I'm one hundred percent sure about Edward, "I told him without missing a beat. "Getting married, though? What's the rush?" He eyed me suspiciously again. The rush was due to the fact that I was getting closer to nineteen every stinking day, while Edward stayed frozen in all his seventeen-yearold perfection, as he had for over ninety years. Not that this fact necessitated marriage in my book, but the wedding was required due to the delicate and tangled compromise Edward and I had made to finally get to this point, the brink of my transformation from mortal to immortal. (pg. 14 engaged-Breaking dawn)

This data explained that Bella's conviction to marry Edward was something that according to Charlie was a fairly hurried decision to carry out marriage, wherein that Edward and Bella had to give up their youth. Bella is so sure of their decision to get married, but on the other hand Bella must also give up being an immortal creature like Edward as committed by Bella and Edward.

Commitment by Edward and Bella to get married for the sake of realizing their love even though there are some things they have to sacrifice. Commitment is the desire and sincerity to maintain relationships even though they are full of difficulties and sacrifices (Yudisia, 2013).

Our vows were the simple, traditional words that had been spoken a million times, though never by a couple quite like us. We'd asked Mr. Weber to make only one small change. He obligingly traded the line "till death do us part" for the more appropriate "as long as we both shall live. (Pg. 45 big day-Breaking dawn).

This data explains that the faithful promise between Edward and Bella is somewhat different from the others. The faithful promise made by the two of them before Mr. Weber.

Commitment in this data is shown in the faithful promises made by Bella and Edward before the prince Mr. Weber at his wedding. That they promise to live together as long as they live until death can separate. As explained Dariyo (2008), that true commitment is a commitment that comes from within that will never fade despite facing various obstacles, temptations or severe tests in the life of his love journey.

Jacob, I thought, despite myself. Though that yearning was both vanished and defined, and I was vastly relived that it was, he was still my friend. 
Someone who knew the real me and accepted her. Even as a monster.(Pg. 424 memories-breaking dawn).

Bella is reminded by Jacob's words about her drama with Bella, that Jacob is always there when Bella needs him.

The commitment in this data shows that Jacob is committed to always be there for Bella, even though he has no ties beyond Bella's best friend relationship. but Jacob who has committed to what Jacob did to Bella who always protect Bella. on every trip Bella, Jacob is always there if Bella needs him. Commitment is the desire and sincerity to maintain relationships even though they are full of difficulties and sacrifices (Yudisia, 2013).

"It's all about balance, love. You're so good at all of this, I don't imagine it will take too long to put everything in perspective." "And we have all night, right?" He smiled wider. "Do you think I could bear to let you get dressed now if that weren't the case?" That would have to be enough to get me through the daylight hours. I would balance this overwhelming, devastating desire so that I could be a good, It was hard to think the word. Though Renesmee was very real and vital in my life, it was still difficult to think of myself as a mother. I supposed anyone would feel the same, though, without nine months to get used to the idea. And with a child that change by the hour. (Pg. 451 favor-breaking dawn).

Bella and Edward, who must arrange time for the two of them with their little daughter and about their passion for the two, must be balanced by looking after her little daughter.

The commitment in this data is shown in the commitment they made to better manage their time together with their little daughter. The difficulties they face to always take the time to be together they have to sacrifice in order to maintain time with their little daughter. As said by Yudisia (2013) Commitment is the desire and sincerity to maintain relationships even though they are full of difficulties and sacrifices.

So this was really different. I was amazing now, to them and to myself. It was like I had been born to be a vampire. The idea made me want to laugh, but it also made me want to sing. I had found my true place in the world, the place I fit, the place I shined. (Pg. 485 shiny-breaking dawn). 
This data explains that Bella, who has been thinking that she herself is accustomed to her new life with Edward and does not feel burdened, even thinks that she was born to be a vampire.

The commitment in this data shows that Bella managed to live her life after becoming an immortal being, where being an immortal was the agreement she made with Edward when they became lovers. then the commitment was automatically made marked by the strengthening of Bella's words that said that he was born to be a vampire, even though it was very difficult to live with so many sacrifices that Bella had to undergo, and gave up to become an immortal or vampire. Unlike intimacy and passion, commitment increases slowly at the beginning of a relationship. Over time, when couples have long-term goals, commitment will continue to grow (Sternberg, 2009).

"Bella is her biological mother," Edward told her. "She conceived, carried, and gave birth to Renesmee while she was still human. It nearly killed her. I was hard-pressed to get enough venom into her heart to save her." (Pg. 543 irrestible-breaking down).

This data explains that Edward had told Renesmee that she was the biological child of Bella and Edward, and Bella was still human at that time. At that moment Edward was struggling to save Bella's life to keep the fetus in her womb until Renesmme could be born. This data also explains that Edward, who so loved Bella, where Edward who had tried to loved Bella, where Edward who had tried to still be able to save Bella even though Edward had to sacrifice himself to save Bella.

Commitment in this data when Edward who has promised to keep Bella so Edward with all her might save Bella who was almost killed. Edward, who really loves Bella with full commitment to establish a relationship with Edward's responsibility to protect Bella, tries as much as Edward can to save Bella. Edward's efforts are committed to always accompany Bella and do not want to be separated from Bella. As said by Yudisia (2013) Commitment is the desire and sincerity to maintain relationships even though they are full of difficulties and sacrifices. 


\section{CONCLUSION AND SUGGESTION}

The writer drew the conclusion from this study, that the love story is intertwined with several characters in this novel. The author raised the love story between Edward with Bella and Jacob who became Bella's best friend by using the theory of triangular of love by Sternberg, including Intimacy, passion and commitment. Edward and Bella on the intimacy side are very clearly seen with the feeling of love that exists between the two. This also happens between Bella's relationship with Jacob who both have communication that looks intimidating because they both have feelings of love towards friends. Passion that means feeling always wants to be together with physical closeness.

In this novel it is seen where Edward and Bella always want to live together and do not want to be separated from each other. As for the passion of Jacob who wants to have a closer relationship with Bella even though Jacob knows that Bella only loves Edward. What distinguishes it between Edward, Bella and his friend Jacob is on the commitment side. Where Edward and Bella have engaged and they have made a loyal promise.

The writer suggests that the readers take this novel to be used as literary study material. because not only the love story that can be taken from this novel, but there are some studies that can be taken including, concerning social culture for groups of people who have become immortal beings or vampires. Because, seen from the novel breaking dawn of their lives only includes night life and their habit of getting food by hunting and relying on the sense of smell and they also eat sucking raw meat from animals and humans.

\section{REFERENCES}

Dariyo, Agoes. (2003). Psikologi Perkembangan Dewasa Muda. Jakarta: PT. Gramedia Widiasarana.

(2008). Psikologi Perkembangan Dewasa Muda. Jakarta: Grasindo.

Ahmadi, Abu. 2002. Psikologi Sosial. Jakarta: Rineka Cipta

Baron, R. A. \& Byrne, D. (2005). Psikologisosial (10th ed.). Jakarta: Erlangga 
Endaswara, Suwardi. 2011. Metodologi Penelitian Sastra. Jakarta: Kav Maduskimo.

Fananie, Zainuddin. 2000. Telaah Sastra. Surakarta: Muhammadiyah University Press.

Kroger, J. (2001). Identity Development Adolescene Trough Adulthood. London: Sage Publication, Inc. Learning.

Marcia, J.E., Waterman, et al. (1993). Ego Identity A Handbook for Psychosocial Research. New York: Springer-Verlag.

Nevid, Jeffrey S., Spencer. A. Rathus, dan Greene, Beverly. 2005. Psikologi Abnormal: Terjemahan Tim Psikologi Universitas Indonesia. Edisi Kelima. Jilid1. Jakarta: Penerbit Erlangga.

Nurgiyantoro, B. (2010). Penilaian Pembelajaran Bahasa. Yogyakarta: BPFE

Tarigan, Henry Guntur. 1991. Prinsip-Prinsip Dasar Sastra. Bandung: Angkasa

Nurgiyantoro, Burhan.2007. Teori Pengkajian Fiksi. Yogyakarta: Gajah Mada University Press.

Prawira, Purwa 2016. Psikologi Umum Dengan Prespektif Baru. Ar-Ruz Media. Depok, Sleman Jakarta. psychology (6th Ed.). Belmont, CA: Wadsworth, Cengage

Ratna, Nyoman Kutha. 2004. Teori, Metode, Dan Teknik Penelitian Sastra (Dari Strukturalisme Hingga Postrukturalisme, Perspektif Wacana Naratif). Yogyakarta: Pustaka Pelajar.

Santrock, John W. 2002. Life-span Development : Perkembangan Masa Hidup. Edisi 5 jilid 2, Jakarta : Erlangga

Semi, Atar. 1993. Metode Penelitian Sastra. Bandung : Angkasa.

Steers, R.M dan Porter, L.W. 1983. Motivation and Work Behavior, New York: Acadaemic Press.

Sternberg, R.J. (1986).A triangular love theory of love. Psychological review. Vol 93 no. 2. 119-135. American Psychology Asociation, Inc.

(2009). Cognitive psychology (6th Ed). Belmont, CA: Wadsworth, Cengage Learning.

Sugiono. 2009. Metode penelitian bisnis (pendekatan kuantitatif, kualitatif, dan R\&D). Bandung : Alfabeta.

Sumardjo, Jakob. 1984. Masyarakat dan Sastra Indonesia. Jakarta: Nur Cahaya. 
Taylor, S.E., Peplau, L.A., and Sears, D.O. 2009. Psikologi Sosial. Edisi Keduabelas. Alih Bahasa: Tri Wibowo, B.S. Jakarta: Kencana Prenada Media Group

Widodo, Suparno Eko. 2015. Manajemen Pengembangan Sumber Daya Manusia. Yogyakarta: Pustaka Pelajar.

Wisnu and Mashoedi. (2012). Hubungan Interpersonal. Jakarta. Salemba Humanika

Yudisia, Sinta. 2013. Kitab Cinta dan Patah Hati. Surakarta: Indiva. 